\title{
Miscellaneous Diterpenes from the Aerial Parts of Plectranthus ornatus Codd
}

\author{
Fábio N. Ávila, ${ }^{a}$ Francisco C. L. Pinto, ${ }^{a}$ Thiciana S. Sousa, ${ }^{a}$ Maria Conceição M. Torres, \\ Leticia V. Costa-Lotufo, ${ }^{b, c}$ Danilo D. Rocha, ${ }^{b}$ Mayron A. de Vasconcelos, ${ }^{d}$ \\ Nairley Cardoso-Sá, ${ }^{d}$ Edson H. Teixeira, ${ }^{d}$ Maria Rose Jane R. Albuquerque, ${ }^{e}$ \\ Edilberto R. Silveira ${ }^{a}$ and Otília D. L. Pessoa*,a \\ ${ }^{a}$ Departamento de Química Orgânica e Inorgânica, Universidade Federal do Ceará, \\ 60021-970 Fortaleza-CE, Brazil \\ ${ }^{b}$ Departamento de Fisiologia e Farmacologia, Universidade Federal do Ceará, \\ 60430-270 Fortaleza-CE, Brazil \\ 'Departamento de Farmacologia, Universidade de São Paulo, 05508-900 São Paulo-SP, Brazil \\ ${ }^{d}$ Laboratório Integrado de Biomoléculas, Departamento de Patologia e Medicina Legal, \\ Universidade Federal do Ceará, 60441-750 Fortaleza-CE, Brazil \\ ${ }^{e}$ Coordenação de Química, Centro de Ciências Exatas e Tecnológicas, \\ Universidade Estadual Vale do Acaraú, 62040-340 Sobral-CE, Brazil
}

Five new diterpenes derivatives named as ornatin A, B, C, D and E, in addition to six known related diterpenes were isolated from the aerial parts of cultivated specimens of Plectranthus ornatus. The structures were elucidated using a combination of $1 \mathrm{D} / 2 \mathrm{D}$ nuclear magnetic resonance (NMR) spectroscopy, high-resolution electrospray ionization mass spectrometry (HRESIMS) and comparison with published NMR data of analogous compounds. All isolated compounds were assayed against four human cancer cell lines, and Gram-positive and Gram-negative bacteria strains. None of them showed any cytotoxic activity, but ornatin C, D, E and three related diterpenes displayed marginal bactericidal or bacteriostatic effects against the Gram-positive strains.

Keywords: Plectranthus ornatus, diterpenes, ent-clerodanes, bacteriostatic

\section{Introduction}

The genus Plectranthus L'Her (Lamiaceae, subfamily Nepetoideae, tribe Ocimeae, subtribe Plectranthinae) comprises approximately 300 species largely distributed over the African, Asian and Australian continents. ${ }^{1}$ Plectranthus is a large genus well known by its diversity of ethnobotanical uses, being especially indicated to treat digestive disorders, skin diseases, infections and respiratory problems. ${ }^{2}$ In general, are rich source of essential oils, terpenoids and phenol compounds. ${ }^{3}$ Pharmacological properties such as anti-inflammatory, ${ }^{4}$ antioxidant, ${ }^{5}$ antimicrobial, ${ }^{6}$ anti-tumoral ${ }^{7}$ and diuretic ${ }^{8}$ have been demonstrated for several isolated compounds from Plectranthus, corroborating with its larger medicinal uses.
Plectranthus ornatus Codd (syn. Coleus comosus Hochst. ex Gurke) is a perennial and aromatic herb, widespread around the new world. ${ }^{9}$ In the northeast of Brazil, P. ornatus, popularly known as "malva santa" or "boldo miúdo", is cultivated as a very important medicinal plant, indicated as analgesic and particularly to treat gastric disorders. ${ }^{10}$ Several antimicrobial labdanes, ent-clerodanes, and halimane-type diterpenoids have been previously isolated from $P$. ornatus. ${ }^{11}$ As part of a multidisciplinary program, where the efforts are devoted to study medicinal plants or congeners, in order to unveil their pharmacological or biological properties, herein we describe the isolation and characterization of five new diterpenes derivatives together with six known compounds from the aerial parts of cultivated specimens of P. ornatus, as well as the results of pharmacological and biological assays with the isolated secondary metabolites (Figure 1).

*e-mail: otilialoiola@gmail.com 
<smiles>COC(=O)/C=C(\C)CC(OC(C)=O)[C@H]1[C@@H](C)CC[C@H]2C(C)=CCC[C@H]12</smiles>

1

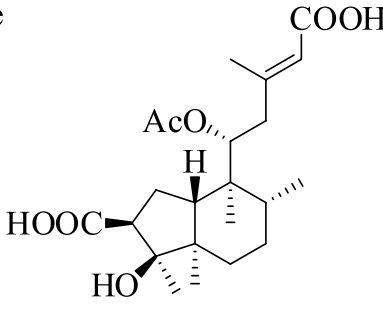

2<smiles>CC(=O)OC(C/C(C)=C/C(=O)O)[C@H]1[C@@H](C)CC[C@@H]2[C@@H]1CC[C@H](O)[C@@]2(C)O</smiles>

3

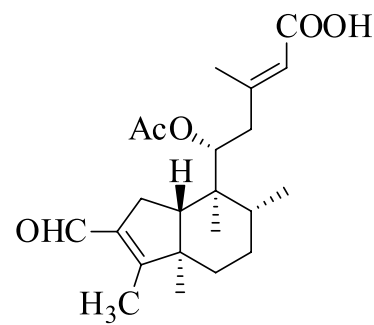

4<smiles>C=C1C=CC[C@H]2[C@H]1CC[C@@H](C)[C@H]2CC(=O)[C@H](C)/C=C(\C)C(=O)O</smiles>

5<smiles></smiles>

6

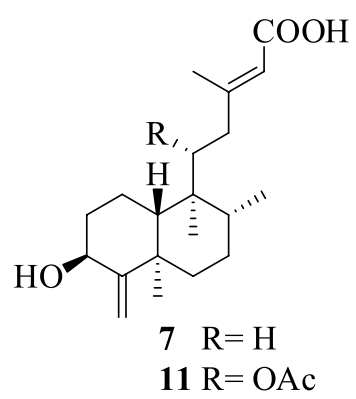

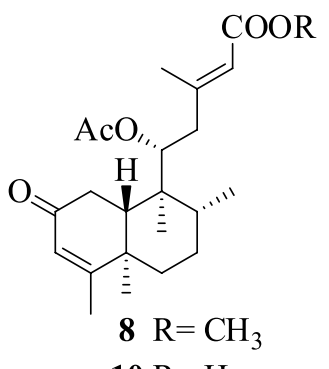

$10 \mathrm{R}=\mathrm{H}$<smiles>C/C(=C/C(=O)O)CC[C@H]1[C@@H](O)CC[C@H]2[C@@H](C)CCCC[C@@]21C</smiles>

Figure 1. Structure of compounds 1-11 isolated from P. ornatus.

\section{Experimental}

\section{General experimental procedures}

Optical rotations were measured on a PerkinElmer 341 digital polarimeter. Infrared (IR) spectra were obtained on a PerkinElmer FT-IR spectrum 1000 spectrometer. Accurate mass spectra were acquired on a liquid chromatography-mass spectrometry ion-trap and time-of-flight (LCMS-IT-TOF, Shimadzu) spectrometer. Nuclear magnetic resonance (NMR) spectra were performed either on Bruker DPX-300 or DRX-500 spectrometers. Open column chromatography (CC) were carried out with silica gel (60 or 230 mesh, Merck) and Sephadex LH-20 (Phenomenex), while thin layer chromatography (TLC) were conducted on precoated silica gel aluminum sheets $\left(60 \mathrm{~F}_{254}, 0.20 \mathrm{~mm}\right.$, Merck). Semi preparative Gemini-Phenomenex C-18 column $(150 \times 10 \mathrm{~mm})$ was used on an ultra-fast liquid chromatography (UFLC, Shimadzu) system equipped with a SPD-M20A diode array UV-Vis detector. High performance liquid chromatography (HPLC) procedures were carried out using UV PDA detection 210-400 nm, injection volume $200 \mu \mathrm{L}$, and flow rate of $4.72 \mathrm{~mL} \mathrm{~min}^{-1}$.

\section{Plant material}

Plectranthus ornatus was harvested in May 2012 at the medicinal plant garden Francisco José de Abreu Matos, Universidade Federal do Ceará (UFC). The plant authentication was performed by Dr Maria Iracema B. Loiola from the Herbario Prisco Bezerra (EAC), UFC, where a voucher (No. 56806) was deposited.

\section{Extraction and isolation}

The air-dried and powdered aerial parts of $P$. ornatus (1.50 kg, $7.5 \%$ of fresh weight) was extracted with $n$-hexane followed by $\mathrm{EtOH}(3 \times 13 \mathrm{~L})$, at room temperature, to give the respective crude extracts after the solvents evaporation under reduced pressure. The $n$-hexane extract (30.00 g, $0.22 \%$ of dry weight) was subjected to a chromatography column (CC) over silica gel 
eluted with binary mixture of $n$-hexane/EtOAc (100:0, 7:3, $1: 1,3: 7,0: 100)$ to yield ten fractions (FA-FJ). FC (2.8 g) was subjected to silica gel CC and eluted with increasing amounts of $n$-hexane in EtOAc to yield compound $\mathbf{1}$ $(50.7 \mathrm{mg})$, which was obtained by elution with $n$-hexaneEtOAc 8:2. FG (573.6 mg) was chromatographed on a Sephadex LH-20 CC and eluted with $\mathrm{MeOH}$ to yield four subfractions (FG.1-FG.4). Subfraction FG.3 (350.6 mg) was subjected to CC silica gel column eluted with $n$-hexane-EtOAc (95:5, 90:10, 80:20, 75:25, 70:30, 60:40, $1: 1)$ to afford seven subfractions (FG.3-1-FG.3-7) from which FG.3-1 (256.6 mg) was further purified by HPLC using a semi preparative C-18 column and a solvent system constituted of $\mathrm{H}_{2} \mathrm{O}$ (TFA $0.1 \%$ )/MeOH (30:70) to $100 \% \mathrm{MeOH}$ over $15 \mathrm{~min}$, followed by $10 \mathrm{~min}$ of $100 \%$ $\mathrm{MeOH}$, to give $2\left(12.0 \mathrm{mg}, \mathrm{t}_{R}=7.85\right)$ and $\mathbf{3}(23.1 \mathrm{mg}$, $\left.\mathrm{t}_{R}=9.35\right)$. FH (2.2 g) was subjected to repeated CC over silica gel, always using $n$-hexane-EtOAc gradient mixtures to afford two main fractions FH1 (167.8 mg) and FH2 (146.5 mg). Both were subjected to HPLC using a semi preparative $\mathrm{C}-18$ column and in the mobile phase, a gradient consisting of $\mathrm{H}_{2} \mathrm{O}$ (TFA $0.1 \%$ )/ $\mathrm{MeOH}(35: 65)$ to $100 \% \mathrm{MeOH}$ over $20 \mathrm{~min}$, followed by $10 \mathrm{~min}$ of $100 \%$ $\mathrm{MeOH}$. From FH1 were isolated compounds $6(24.0 \mathrm{mg}$, $\left.\mathrm{t}_{R}=9.43\right)$ and 7 (4.5 mg, $\left.\mathrm{t}_{R}=14.47\right)$, while from $\mathrm{FH} 2$ were obtained compounds $8\left(12.9 \mathrm{mg}, \mathrm{t}_{R}=6.82\right)$ and $\mathbf{9}(6.7 \mathrm{mg}$, $\left.\mathrm{t}_{R}=11.64\right)$. FI (792.0 g) was subjected to Sephadex LH-20 by elution with $\mathrm{MeOH}$ to afford three main fractions, FI1-FI3. FI2 $(351.8 \mathrm{mg})$ was rechromatographed on Sephadex LH-20 CC eluting with $\mathrm{MeOH}$ to yield subfractions FI2.1 and FI2.2. FI2.2 (276.6 mg) was further subjected to HPLC using a semipreparative C-18 column and a gradient of $\mathrm{H}_{2} \mathrm{O}$ (TFA $\left.0.1 \%\right) / \mathrm{MeOH}(30: 70)$ to $90 \% \mathrm{MeOH}$ over $15 \mathrm{~min}$, followed by $10 \mathrm{~min}$ of $100 \%$ $\mathrm{MeOH}$, to afford 4 (13.4 mg, $\left.\mathrm{t}_{R}=9.03\right), 5(16.4 \mathrm{mg}$, $\left.\mathrm{t}_{R}=11.45\right), \mathbf{1 0}\left(24.0 \mathrm{mg}, \mathrm{t}_{R}=8.09\right)$ and $\mathbf{1 1}(17.0 \mathrm{mg}$, $\left.\mathrm{t}_{R}=9.50\right)$.

\section{Ornatin A (1)}

Colorless resin: $[\alpha]_{\mathrm{D}}^{22}-43.96^{\circ}\left(c \quad 0.1, \mathrm{CH}_{2} \mathrm{Cl}_{2}\right)$; $\mathrm{UV}(\mathrm{MeOH}) \lambda_{\max } / \mathrm{nm} \mathrm{215}$; IR (ATR, attenuated total reflectance) $v / \mathrm{cm}^{-1} 1717,1647,1436,1369,1235,1152$; ${ }^{1} \mathrm{H}$ and ${ }^{13} \mathrm{C} \mathrm{NMR}\left(\mathrm{CDCl}_{3}\right)$, see Tables 1 and 2, respectively; HRESIMS (high-resolution electrospray ionization mass spectrometry) $m / z$, observed: $399.2508 ; \mathrm{C}_{23} \mathrm{H}_{36} \mathrm{O}_{4}$ $[\mathrm{M}+\mathrm{Na}]^{+}$requires 399.2506 .

\section{Ornatin B (2)}

Colorless resin: $[\alpha]_{D}^{22}-34.44^{\circ}\left(c 0.06, \mathrm{CH}_{2} \mathrm{Cl}_{2}\right)$; UV (MeOH) $\lambda_{\text {max }} / \mathrm{nm} 218 ; \mathrm{IR}(\mathrm{KBr}) v / \mathrm{cm}^{-1} 3444,2926,1694$, 1635, 1380, 1235; ${ }^{1} \mathrm{H}$ and ${ }^{13} \mathrm{C}$ NMR (MeOD), see Tables 1 and 2, respectively; HRESIMS $\mathrm{m} / \mathrm{z}$, observed: 433.2197; $\mathrm{C}_{22} \mathrm{H}_{34} \mathrm{O}_{7}[\mathrm{M}+\mathrm{Na}]^{+}$requires 433.2202.

\section{Ornatin C (3)}

Colorless resin; $[\alpha]_{\mathrm{D}}^{22}-48.06^{\circ}(c$ 0.1, MeOH); UV (MeOH) $\lambda_{\max } / \mathrm{nm} 217$; IR (KBr) $v / \mathrm{cm}^{-1} 3436,2934$, 2867, 1711, 1643, 1439, 1244; ${ }^{1} \mathrm{H}$ and ${ }^{13} \mathrm{C}$ NMR $\left(\mathrm{CDCl}_{3}\right)$, see Tables 1 and 2, respectively; HRESIMS $m / z$, observed: 419.2403; $\mathrm{C}_{22} \mathrm{H}_{36} \mathrm{O}_{6}[\mathrm{M}+\mathrm{Na}]^{+}$requires 419.2404.

\section{Ornatin D (4)}

Greenish oil; $[\alpha]_{\mathrm{D}}^{22}-47.50^{\circ}\left(c 0.1, \mathrm{CH}_{2} \mathrm{Cl}_{2}\right) ; \mathrm{UV}(\mathrm{MeOH})$ $\lambda_{\max } / \mathrm{nm} 219$; IR (ATR) $v / \mathrm{cm}^{-1} 3452,2926,2876,1734$, $1691,1641,1238,1149,1020 ;{ }^{1} \mathrm{H}$ and ${ }^{13} \mathrm{C}$ NMR $\left(\mathrm{CDCl}_{3}\right)$, see Tables 1 and 2, respectively; HRESIMS $m / z$, observed: 399.2114; $\mathrm{C}_{22} \mathrm{H}_{32} \mathrm{O}_{5}[\mathrm{M}+\mathrm{Na}]^{+}$requires 399.2142.

\section{Ornatin E (5)}

Colorless resin; $[\alpha]_{\mathrm{D}}^{22}-47.50^{\circ}\left(c 0.1, \mathrm{CH}_{2} \mathrm{Cl}_{2}\right)$; UV (MeOH) $\lambda_{\max } / \mathrm{nm} 218$; IR (ATR) $v / \mathrm{cm}^{-1} 3396,2925,1736$, $1688,1641,1435,1237,1207 ;{ }^{1} \mathrm{H}$ and ${ }^{13} \mathrm{C}$ NMR $\left(\mathrm{CDCl}_{3}\right)$, see Tables 1 and 2, respectively; HRESIMS $m / z$, observed: 399.2495; $\mathrm{C}_{22} \mathrm{H}_{32} \mathrm{O}_{4}[\mathrm{M}+\mathrm{K}]^{+}$requires 399.1938.

\section{Cytotoxicity evaluation - MTT assay}

Cytotoxicity was evaluated against four different human cancer cell lines provided by the National Cancer Institute U.S. (Bethesda, MD): HCT-116 (colon adenocarcinoma), HL-60 (leukemia), OVCAR-8 (ovarian carcinoma) and SF-295 (glioblastoma). Cells were maintained in RPMI 1640 medium supplemented with $10 \%$ fetal bovine serum (v/v), $2 \mathrm{mmol} \mathrm{L}^{-1}$ glutamine, $100 \mathrm{U} \mathrm{mL}^{-1}$ penicillin, $100 \mu \mathrm{g} \mathrm{mL} \mathrm{L}^{-1}$ streptomycin at $37{ }^{\circ} \mathrm{C}$ under a $5 \% \mathrm{CO}_{2}$ atmosphere. Cytotoxicity was also evaluated against peripheral blood mononuclear cells (PBMC) obtained from the peripheral blood of healthy volunteers after centrifugation on a Ficoll gradient. Cells were removed, washed with phosphate buffered saline (PBS) and resuspended in a RPMI 1640 medium supplemented with $20 \%$ of fetal bovine serum, $100 \mathrm{U} \mathrm{mL}^{-1}$ penicillin and $100 \mu \mathrm{g} \mathrm{mL}^{-1}$ of streptomycin to a final concentration of $3 \times 105$ cell $\mathrm{mL}^{-1}$. Phytohemagglutinin (3\%) was added to induce cell proliferation. Compounds 1-11 were tested at concentrations ranging from 0.05 to $25 \mu \mathrm{mol} \mathrm{L} \mathrm{L}^{-1}$ during $72 \mathrm{~h}$. The effect on cell proliferation was evaluated in vitro using the MTT [3-(4,5-dimethyl-2-thiazolyl)2,5-diphenyl-2 $\mathrm{H}$-tetrazolium bromide] assay, as described by Mosmann. ${ }^{12} \mathrm{IC}_{50}$ (the concentration that inhibits growth in 50\%) values were calculated by non-linear regression using the software GraphPad Prism 5.0. Doxorubicin 
(Sigma Aldrich Co.) was used as positive control (0.01 to $5 \mu \mathrm{mol} \mathrm{L}^{-1}$ ), while the vehicle used to dilute the substances, DMSO at a final concentration of $0.5 \%$, was used as negative control.

\section{Antibacterial assay}

The antibacterial activity of the diterpenes was evaluated against four bacteria: Staphylococcus aureus ATCC 25923, S. epidermidis ATCC 12128, Pseudomonas aeruginosa ATCC 9027 and Escherichia coli ATCC 11303. Before experimental procedures, each bacterial species was grown in tryptic soy agar (TSA, Himedia, USA) for $24 \mathrm{~h}$ at $37{ }^{\circ} \mathrm{C}$. The cells were inoculated in tryptic soy broth (TSB, Himedia, USA) and incubated for $18 \mathrm{~h}$ at $37^{\circ} \mathrm{C}$ under constant agitation. Subsequently, cell's concentration of each bacterium was adjusted to $1 \times 10^{6}$ cell $\mathrm{mL}^{-1}$ using spectrophotometry and calibration curves previously determined. The minimal inhibitory concentration (MIC) and minimal bactericidal concentration (MBC) were determined by the broth microdilution method according with the guidelines from the National Committee for Clinical Laboratory Standards, M7-A6 (NCCLS, 2003), ${ }^{13}$ with some modifications. Briefly, different concentrations of the compounds ( 7.8 to $500 \mu \mathrm{g} \mathrm{mL}^{-1}$ ) were prepared in TSB (with $4 \%$ of dimethyl sulfoxide) and aliquots of $100 \mu \mathrm{L}$ of each compound were mixed with bacterial suspensions $(100 \mu \mathrm{L})$ in the 96-well polystyrene plates. The plates were incubated at $37^{\circ} \mathrm{C}$ during $24 \mathrm{~h}$ under constant agitation. The MIC value was established as the lowest concentration of compound able to inhibit the visible growth of microorganism. MBC value was determined by transferring $10 \mu \mathrm{L}$ from each well without visible growth into TSA plates. MBC was considered the lowest concentration that completely inhibited microbial growth in the plates.

\section{Results and Discussion}

The chromatographic fractionation of the $n$-hexane extract from the aerial parts of $P$. ornatus was performed, leading to the isolation of five new diterpenes which were designated as ornatins A-E (1-5), as well as the known diterpenes: coleon $\mathrm{R}(\mathbf{6}),{ }^{14}$ ent-3 $\alpha$-hydroxycleroda-4(18), $13 E$-dien-15-oic acid (7), ${ }^{15}$ plectrornatin $\mathrm{A}(\mathbf{8}),{ }^{16}$ labd-13-en$8 \beta$-hydroxy-15-oic acid (9), ${ }^{17} 11$-acetoxy-2-oxo-entcleroda-3,13E-dien-15-oic acid $(\mathbf{1 0})^{18}$ and ent-11R-acetoxy2-oxocleroda-3,13E-dien-15-oic acid (11). ${ }^{16}$

Compound $\mathbf{1}$, isolated as an colorless resin, $[\alpha]_{\mathrm{D}}^{22}$ $-43.96^{\circ}$ ( $c 0.1, \mathrm{CH}_{2} \mathrm{Cl}_{2}$ ), had its molecular formula assigned as $\mathrm{C}_{23} \mathrm{H}_{36} \mathrm{O}_{4}$ based on the $[\mathrm{M}+\mathrm{Na}]^{+}$ion peak at $\mathrm{m} / \mathrm{z} 399.2508$ (calcd. $399.2506, \Delta+0.50 \mathrm{ppm}$ ) in the HRESI mass spectrum. The ${ }^{1} \mathrm{H}$ NMR spectrum showed signals to olefinic protons at $\delta_{\mathrm{H}} 5.64(\mathrm{~s}, 1 \mathrm{H}, \mathrm{H}-14)$ and $5.19(\mathrm{~s}, 1 \mathrm{H}$, $\mathrm{H}-3)$, to an oxymethine proton at $\delta_{\mathrm{H}} 5.44(\mathrm{~d}, 1 \mathrm{H}, J 10.9 \mathrm{~Hz}$, H-11) and a methoxyl at $\delta_{\mathrm{H}} 3$.66. In addition, were observed six methyl signals, two of which attached to $\mathrm{sp}^{2}$ carbons at $\delta_{\mathrm{H}} 2.14(\mathrm{~s}, 3 \mathrm{H}, \mathrm{Me}-16)$ and 1.57 (s, 3H, Me-18), another one of an acetoxyl group at $\delta_{\mathrm{H}} 1.99$ (s, 3H, C-11'), two others attached to quaternary carbons $\left(\delta_{\mathrm{H}} 0.76, \mathrm{Me}-20\right)$ and $\delta_{\mathrm{H}} 1.04$ (s, 3H, Me-19), and the last one attached to a tertiary carbon $\delta_{\mathrm{H}} 0.97(\mathrm{~d}, 3 \mathrm{H}, J 6.1 \mathrm{~Hz}, \mathrm{Me}-17)$. The ${ }^{13} \mathrm{C}$ NMR spectrum showed 23 carbon signals, assigned through the composite pulse decoupling (CPD), distortionless enhancement by polarization transfer (DEPT 135) and heteronuclear single quantum correlation (HSQC) spectra, into seven methyls, six methylenes, five monohydrogenated, including two methine, one oxymethine and two $\mathrm{sp}^{2}$ carbons, and six non-hydrogenated carbons including four $\mathrm{sp}^{2}$ hybridized carbons at $\delta_{\mathrm{C}} 170.8$ (C-11'), 166.7 (C-15), 144.5 (C-4) and $158.1(\mathrm{C}-13)$ and two quaternary carbons at $\delta_{\mathrm{C}} 38.7$ (C-5) and 43.4 (C-9). The ${ }^{1} \mathrm{H}$ and ${ }^{13} \mathrm{C}$ NMR spectral data (Tables 1 and 2) of $\mathbf{1}$ were similar to those reported for the diterpenes 11-acetoxyneoclerodane, which were previously isolated of the P. ornatus. ${ }^{19}$ The only difference between these two compounds was the replacement of the carboxyl function at C-15 $\left(\delta_{\mathrm{C}} 171.7\right)$ for a methyl ester $\left(\delta_{\mathrm{C}} 166.7\right.$, $\left.51.0 / \delta_{\mathrm{H}} 3.66\right)$. The double bond C-13/C-14 was defined as $E$ based on chemical shifts (see Table 1) in agreement with previous diterpenes isolated of P. ornatus. ${ }^{16}$ As can be seen in the Experimental section, no $\mathrm{MeOH}$ has been used during any extraction or chromatographic procedures, thus, eliminating the possibility of $\mathbf{1}$ being an artifact. The final structure of $\mathbf{1}$ was confirmed by the heteronuclear multiple bond correlation (HMBC) spectrum through the selected long-range correlations depicted by arrows in Figure 2, while its relative stereochemistry was established by the nuclear Overhauser spectrum (NOESY) (see Supplementary Information). The trans-configuration for the $\mathrm{A}$ and $\mathrm{B}$ rings of the decaline moiety was confirmed by the dipolar coupling effect (NOE) between $\mathrm{H}-8 / \mathrm{H}-10$ and Me-19/Me-20 both set in a 1,3-diaxial relationship. The observed NOE's for Me-20 with Me-17 and Me-11' (methyl of the acetoxyl group) confirmed the $\alpha$-position inferred for both AcO-11' and Me-17 (Figure 3), also in agreement with the stereochemistry reported previously for $11 R^{*}$ diterpenes from $P$. ornatus. ${ }^{16,18}$ Thus, compound 1 was assigned as the ent-clerodane diterpene designated as ornatin $\mathrm{A}$, in allusion to the species.

Compound 2, obtained as a colorless resin, $[\alpha]_{\mathrm{D}}^{22}$ $-34.44^{\circ}$ ( $c 0.06, \mathrm{CH}_{2} \mathrm{Cl}_{2}$ ), had its molecular formula determined as $\mathrm{C}_{22} \mathrm{H}_{34} \mathrm{O}_{7}$ based on the $[\mathrm{M}+\mathrm{Na}]^{+}$ion peak found at $m / z 433.2197$ (calcd. 433.2202, $\Delta+0.46$ ppm) in 
the HRESIMS. Its ${ }^{1} \mathrm{H}$ NMR spectrum displayed signals for an olefinic proton at $\delta_{\mathrm{H}} 5.66(\mathrm{~s}, 1 \mathrm{H}, \mathrm{H}-14)$, an oxymethine proton at $\delta_{\mathrm{H}} 5.10(\mathrm{~d}, 1 \mathrm{H}, J 10.3 \mathrm{~Hz}, \mathrm{H}-11)$, and six methyl groups, including one attached to a sp $\mathrm{sparbon}^{2} \delta_{\mathrm{H}} 2.20(\mathrm{~s}$, $3 \mathrm{H}, \mathrm{H}-16)$ and another one of an acetoxyl group at $\delta_{\mathrm{H}} 2.02$ (s, 3H, H-11'). The ${ }^{13} \mathrm{C}$ NMR spectrum exhibited 22 carbon signals, which in accordance with the DEPT 135 and HSQC spectra were defined as six methyls, four methylenes, five monohydrogenated and seven non-hydrogenated carbons, including an olefinic carbon $\delta_{\mathrm{C}} 160.6(\mathrm{C}-13)$, two rid carboxyls $\delta_{\mathrm{C}} 180.3(\mathrm{C}-3)$ and $\delta_{\mathrm{C}} 171.6(\mathrm{C}-15)$, one of which $\alpha, \beta$-unsaturated, and an acetoxyl moiety $\delta_{\mathrm{C}} 170.9$ (C-11'). Comparison of the ${ }^{1} \mathrm{H}$ and ${ }^{13} \mathrm{C}$ NMR data of $\mathbf{2}$ with those of $\mathbf{1}$ showed that these compounds share a partial similarity, but differing markedly in the A ring. In the HMBC spectrum, the long range correlation for the methylene protons $\delta_{\mathrm{H}} 2.15(\mathrm{~m}, 1 \mathrm{H}, \mathrm{H}-1 \mathrm{a})$ with the methine carbons at $\delta_{\mathrm{C}} 51.4$ (C-2) and 45.7 (C-10), and with the carboxyl at $\delta_{\mathrm{C}} 180.3$ (C-3), as well as correlation of the $\delta_{\mathrm{H}} 1.35(\mathrm{~s}, 3 \mathrm{H}, \mathrm{Me}-18)$ with the quaternary carbon at $\delta_{\mathrm{C}} 49.5(\mathrm{C}-5)$ and with an oxygenated non-hydrogenated carbon at 82.7 (C-4) allowed to suggest a rearranged five membered ring bearing a carboxyl group at C-2 and a hydroxyl at C-4. Finally, the relative stereochemistry of $\mathbf{2}$ was established by the NOESY spectrum which showed dipolar couplings for $\mathrm{H}-2 / \mathrm{Me}-18$ and Me-18/Me-19 indicating a $\beta$-position to the carboxyl acid at C-2, while the NOE's of H-8/H-10 and Me-19/ Me-20 supported a trans fusion of the $\mathrm{A} / \mathrm{B}$ rings, as depicted in Figure 3. The stereochemistry of C-11 was suggested as $R^{*}$ in accordance with previously diterpenes isolated from P. ornatus. ${ }^{16,18}$ Thus, the structure of compound $\mathbf{2}$ was established as a new rearranged $(4 \rightarrow 2)$-abeo-clerodane, named as ornatin $\mathrm{B}$.

Compound 3, a colorless resin, $[\alpha]_{\mathrm{D}}^{22}-48.06^{\circ}$ (c 0.1, $\mathrm{MeOH}$ ), had its molecular formula $\mathrm{C}_{22} \mathrm{H}_{36} \mathrm{O}_{6}$ inferred from the $[\mathrm{M}+\mathrm{Na}]^{+}$ion peak at $\mathrm{m} / \mathrm{z} 419.2403$ (calcd. for $\mathrm{C}_{22} \mathrm{H}_{36} \mathrm{O}_{6} \mathrm{Na}, 419.2404, \Delta-0.24 \mathrm{ppm}$ ) as showed through HRESIMS. The ${ }^{1} \mathrm{H}$ NMR spectrum showed signals for an olefinic proton at $\delta_{\mathrm{H}} 5.64(\mathrm{H}-14, \mathrm{~s})$, two oxymethine protons at $\delta_{\mathrm{H}} 5.40(\mathrm{~d}, 1 \mathrm{H}, J 11.2 \mathrm{~Hz}, \mathrm{H}-11)$ and $3.50(\mathrm{br} \mathrm{t}$, $1 \mathrm{H}, J 2.3 \mathrm{~Hz}, \mathrm{H}-3$ ) and signals to six methyl groups, one of which attached to a sp ${ }^{2}$ carbon at $\delta_{\mathrm{H}} 2.20(\mathrm{~s}, 3 \mathrm{H}, \mathrm{H}-16)$ and another one of an acetoxyl group at $\delta_{\mathrm{H}} 1.99(\mathrm{~s}, 3 \mathrm{H}$, $\left.\mathrm{H}-11^{\prime}\right)$. The ${ }^{13} \mathrm{C}$ NMR spectrum showed signals for 22 carbon atoms, accounting for six methyls, five methylenes, five methines including one olefinic $\delta_{\mathrm{C}} 119.6(\mathrm{C}-14)$ and one oxymethine carbons $\delta_{\mathrm{C}} 77.6(\mathrm{C}-3)$. The ${ }^{13} \mathrm{C}$ NMR and DEPT spectra displayed six non-hydrogenated carbons, including one olefinic carbon $\delta_{\mathrm{C}} 158.6$ (C-13), an acetoxyl $\delta_{\mathrm{C}} 172.8\left(\mathrm{C}-11^{\prime}\right)$ and a conjugated acid carboxyl $\delta_{\mathrm{C}} 169.7$ (C-15). The ${ }^{13} \mathrm{C}$ NMR data of $\mathbf{3}$ were similar to those of $\mathbf{1}$, except by the appearance of two carbon signals at $\delta_{\mathrm{C}} 77.6$ and $\delta_{\mathrm{C}} 76.9$ corresponding to the hydroxylation of C-3 and $\mathrm{C}-4$, instead the carbon-carbon double bond. Based on the HSQC spectrum the carbon signal at $\delta_{\mathrm{C}} 77.6$ exhibited correlation with the proton signal at $\delta_{\mathrm{H}} 3.50(\mathrm{br} t, J 2.3 \mathrm{~Hz}$, $\mathrm{H}-3$ ). Comparing these data with those of $3 \beta, 4 \beta$ and $3 \alpha, 4 \beta-$ dihydroxylated ent-clerodane diterpenes from literature, ${ }^{20,21}$ the structure of compound $\mathbf{3}$ was established as the $3 \alpha, 4 \beta$ derivative which was named as ornatin $\mathrm{C}$.

Compound 4, a greenish oil, $[\alpha]_{D}^{22}-47.50^{\circ}$ (c 0.1, $\mathrm{CH}_{2} \mathrm{Cl}_{2}$ ), had its molecular formula $\mathrm{C}_{23} \mathrm{H}_{38} \mathrm{O}_{6}$ determined by HRESIMS through the ion peak $[\mathrm{M}+\mathrm{Na}]^{+}$at $m / z 399.2114$ (calcd. for $\mathrm{C}_{22} \mathrm{H}_{32} \mathrm{O}_{5} \mathrm{Na}, 399.2142, \Delta+1.75 \mathrm{ppm}$ ). The ${ }^{1} \mathrm{H}$ NMR spectrum showed signals for an aldehyde proton at $\delta_{\mathrm{H}} 9.93(\mathrm{~s}, 1 \mathrm{H}, \mathrm{H}-3)$, an olefinic proton at $\delta_{\mathrm{H}} 5.64(\mathrm{~s}$, $1 \mathrm{H}, \mathrm{H}-14)$, an oxymethine proton at $\delta_{\mathrm{H}} 5.12(\mathrm{dd}, 1 \mathrm{H}, J 9.6$, $2.6 \mathrm{~Hz}, \mathrm{H}-11)$, and six methyl groups, two of which attached to $\mathrm{sp}^{2}$ carbons at $\delta_{\mathrm{H}} 2.12(\mathrm{~s}, 3 \mathrm{H}, \mathrm{H}-16)$ and $1.99(\mathrm{~s}, 3 \mathrm{H}$, $\mathrm{H}-18$ ), and another one of an acetyl group at $\delta_{\mathrm{H}} 1.96$ (s, $\left.3 \mathrm{H}, \mathrm{Me}-11^{\prime}\right)$. The ${ }^{13} \mathrm{C}$ NMR spectrum exhibited 22 carbon signals, classified into six methyls, four methylenes, four methines and seven non-hydrogenated carbons, including two acetoxy carbonyl $\delta_{\mathrm{C}} 170.8\left(\mathrm{C}-11^{\prime}\right), \delta_{\mathrm{C}} 171.4(\mathrm{C}-15)$ and an aldehyde carbonyl $\delta_{\mathrm{C}} 188.9$ (C-3). Two $\alpha, \beta$-conjugated systems $\left[\delta_{\mathrm{C}} 159.6(\mathrm{C}-4), 137.9(\mathrm{C}-2), 188.9(\mathrm{C}-3)\right]$ and $\left[\delta_{\mathrm{C}} 170.7(\mathrm{C}-13), 118.1(\mathrm{C}-14), 171.4(\mathrm{C}-15)\right]$ were assigned as established by the DEPT 135, HSQC and HMBC spectra. Complete ${ }^{1} \mathrm{H}$ and ${ }^{13} \mathrm{C}$ assignments of $\mathbf{4}$ were made using a combination of $1 \mathrm{D}$ and 2D-NMR data and comparison with the NMR data of $\mathbf{2}$ (Tables 1 and 2), where the difference between these compounds were the presence of a double bond at $\mathrm{C} 2 / \mathrm{C} 3$ and an aldehyde function at $\mathrm{C}-2$, instead of a carboxyl acid. This proposition was supported by the HMBC spectrum, which exhibited correlations for the aldehyde proton $\delta_{\mathrm{H}} 9.93(\mathrm{H}-3)$ with the carbon signals at $\delta_{\mathrm{C}} 137.9(\mathrm{C}-2)$ and $\delta_{\mathrm{C}} 28.1(\mathrm{C}-1)$, as well as correlations of $\delta_{\mathrm{H}} 1.99(\mathrm{~s}, 3 \mathrm{H}, \mathrm{Me}-18)$ with $\delta_{\mathrm{C}} 137.9$ $(\mathrm{C}-2)$ and $\delta_{\mathrm{C}} 51.7(\mathrm{C}-5)$. It is worthy of notice that both structures of $\mathbf{2}$ and $\mathbf{4}$ were also supported by comparison of the ${ }^{1} \mathrm{H}$ and ${ }^{13} \mathrm{C}$ NMR data of these with those reported to the rearranged $(4 \rightarrow 2)$-abeo-clerodane diterpenes..$^{22}$ The relative stereochemistry of $\mathbf{4}$, as depicted in Figure 3, was defined by NOESY and literature data, ${ }^{16,18}$ which was similar to compound $\mathbf{2}$. Thus, the structure of compound $\mathbf{4}$, a new $(4 \rightarrow 2)$-abeo-clerodane diterpene, was established and named as ornatin D.

Compound 5, a colorless oil, had its molecular formula $\mathrm{C}_{22} \mathrm{H}_{32} \mathrm{O}_{4}$ determined from the ion peak $[\mathrm{M}+\mathrm{K}]^{+}$at $\mathrm{m} / \mathrm{z} 399.2495$ in the HRESIMS. Its IR spectrum exhibited UV absorption bands at 3393 and $1691 \mathrm{~cm}^{-1}$ for conjugated carboxylic acid, and $1734 \mathrm{~cm}^{-1}$ for an ester function. The 
${ }^{1} \mathrm{H}$ NMR spectrum showed signals for olefinic protons at $\delta_{\mathrm{H}} 6.05(\mathrm{~d}, 1 \mathrm{H}, J 9.5 \mathrm{~Hz}, \mathrm{H}-3), 5.80(\mathrm{~m}, 1 \mathrm{H}, \mathrm{H}-2)$, 5.66 (s, 1H, H-14), 4.80 (s, 1H, H-18a) and 4.66 (s, 1H, $\mathrm{H}-18 \mathrm{~b}$ ), the latter two corresponding to vinyl protons of an exocyclic double bond. In addition, it displayed signals for an oxymethine proton at $\delta_{\mathrm{H}} 5.33(\mathrm{~d}, 1 \mathrm{H}, J 10.3 \mathrm{~Hz}, \mathrm{H}-11)$ and five methyl groups, including a methyl attached to an olefinic carbon at $\delta_{\mathrm{H}} 2.11(\mathrm{~s}, 3 \mathrm{H}, \mathrm{Me}-16)$ and a methyl of an acetoxyl group at $\delta_{\mathrm{H}} 2.01$ (s, 3H, C-11'). The ${ }^{13} \mathrm{C}$ NMR spectrum exhibited signals to 22 carbons atoms assigned as five methyls, five methylenes, six methines and six non-hydrogenated carbons, including four carbon-carbon double bonds and two carboxyl carbons at $\delta_{\mathrm{C}} 171.0(\mathrm{C}-15)$ and $\delta_{\mathrm{C}} 170.8$ (C-11'). The ${ }^{1} \mathrm{H}$ and ${ }^{13} \mathrm{C}$ NMR data of $\mathbf{5}$ were similar to those reported initially to $\mathbf{1 - 4}$, showing differences only for the A ring. A system comprising an exocyclic double bond of conjugated diene located at A ring was confirmed through the long range correlations of the allylic protons $\delta_{\mathrm{H}} 2.40(\mathrm{~m}, 2 \mathrm{H}, \mathrm{H}-1)$ with $\delta_{\mathrm{C}} 128.1$ $(\mathrm{C}-2)$ and $\delta_{\mathrm{C}} 129.1(\mathrm{C}-3)$ and correlations of the exomethylene protons $\delta_{\mathrm{H}} 4.80 ; 4.66$ (s, 1H-18ab) with C-3 and C-5 (Figure 2). Finally, the relative stereochemistry of $\mathbf{5}$ was confirmed by NOESY spectrum, similar to those of compounds 1-4. Based on the aforementioned data, the complete structure of $\mathbf{5}$ was established as a new ent-clerodane diterpene which was named ornatin $\mathrm{E}$.

Following their identification, compounds 1-11 were assessed for cytotoxicity in four human cancer cell lines, HCT-116, HL-60, OVCAR-8 and SF-295. All compounds showed to be non-cytotoxic at tested concentrations $\left(\mathrm{IC}_{50}\right.$ values $>25 \mu \mathrm{M}$, data not shown). The anthracycline, doxorubicin, used as positive control, presented $\mathrm{IC}_{50}$ values ranging from $0.02 \mu \mathrm{M}$ in HCT-116 cells to $0.33 \mu \mathrm{M}$ in SF-295 cells.
Regarding the antibacterial activity, compounds $\mathbf{1}$ through 11 were evaluated by MIC and MBC assay against clinically relevant bacteria. The results showed that some diterpenes were bacteriostatic or bactericidal against Gram-positive bacteria. Compounds 3, 4 and $\mathbf{6}$ showed MIC for $S$. aureus at concentrations of $250 \mu \mathrm{g} \mathrm{mL}^{-1}$ and 7 and 8 at $500 \mu \mathrm{g} \mathrm{mL}^{-1}$. Furthermore, S. epidermidis was susceptible only to compound 5 at $500 \mu \mathrm{g} \mathrm{mL}^{-1}$. Interestingly, only compound $\mathbf{3}$ showed bactericidal effects on $S$. aureus at $500 \mu \mathrm{g} \mathrm{mL}^{-1}$. On the other hand, no compounds were effective against Gram-negative bacteria. The antibacterial results found here corroborates with other studies reporting on the antimicrobial activity of diterpenes..$^{23}$ Moreover, the effective concentration of the diterpenes used in this study were similar to those found for other works. ${ }^{24}$ According Urzúa et al. ${ }^{25}$ the antimicrobial activity of diterpenes occurs by destabilization of the plasma membrane caused by the interaction with the lipid bilayer fatty acids present in its structure. Moreover, some studies showed that diterpenes exhibit antibacterial activity only against Gram-positive bacteria, but not against Gram-negative bacteria. Probably, the outer membrane of the Gram-negative bacteria decreases the permeability of the diterpenes and increases resistance to the action of these compounds.

\section{Conclusion}

Five new diterpenes, along with six known ones, were isolated from the aerial parts of Plecthranthus ornatus. Diterpenes are the most characteristic compounds of the genus Plecthranthus, especially those having the abietane and labdane skeletons. However, previous work on P. ornatus have reported it, instead, as a prolific source of clerodane
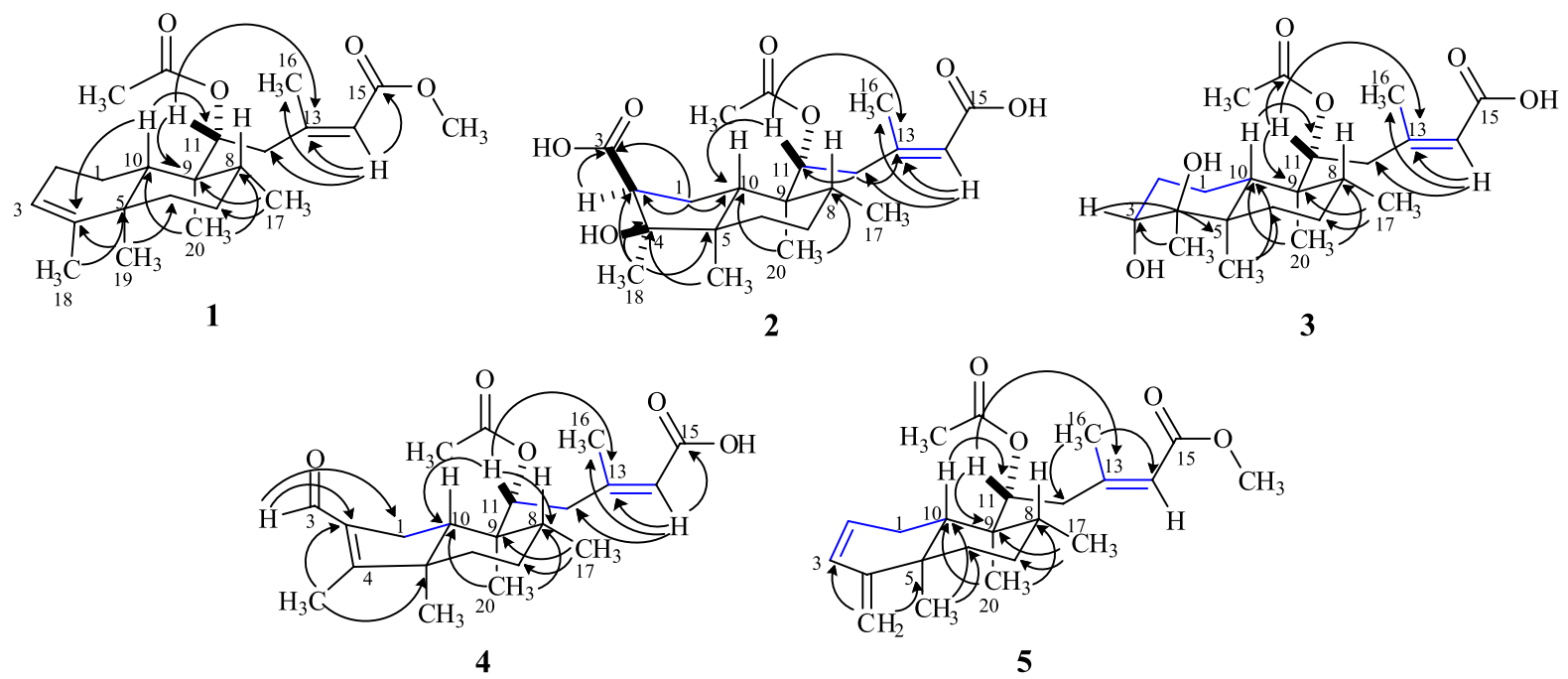

Figure 2. Important COSY $(\longrightarrow$ ) and HMBC $(\frown$ ) correlations for compounds 1-5. 

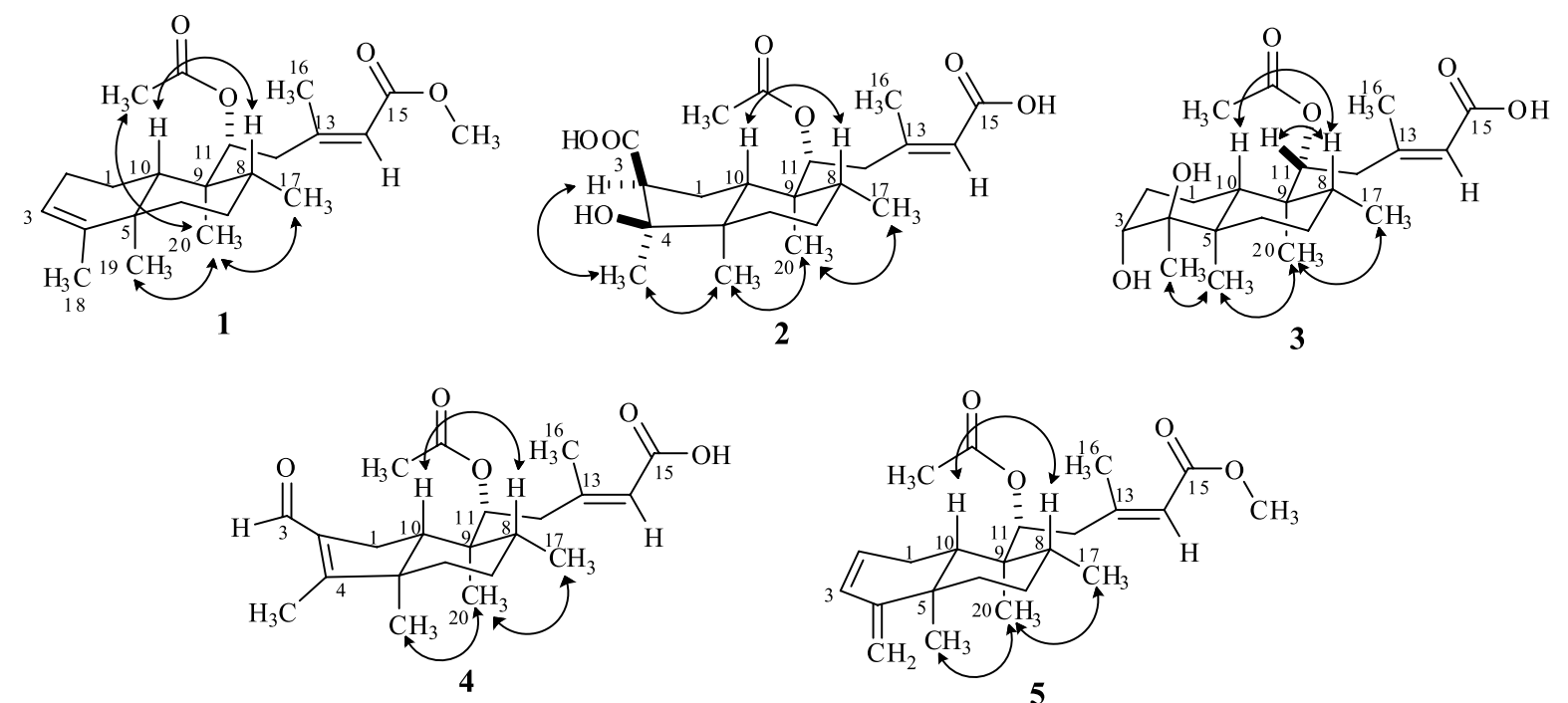

Figure 3. Diagnostic NOESY correlations for compounds 1-5.

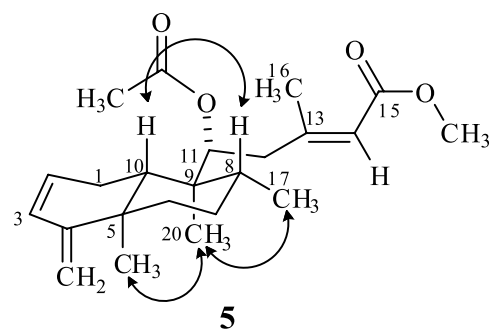

Table 1. ${ }^{1} \mathrm{H}$ NMR data for compounds 1, 2, 4 and $5\left(\mathrm{CDCl}_{3}\right)$, and $\mathbf{3}(\mathrm{MeOD})$

\begin{tabular}{|c|c|c|c|c|c|}
\hline Position & $\mathbf{1}^{\mathrm{a}}$ & $2^{\mathrm{a}}$ & $3^{\mathrm{b}}$ & $4^{a}$ & $5^{\mathrm{b}}$ \\
\hline 1 & $\begin{array}{c}1.86(\mathrm{dd}, 1 \mathrm{H}, J 13.5 \\
\left.12.0 \mathrm{~Hz}, \mathrm{CH}_{2}\right) \\
1.65\left(\mathrm{~m}, 1 \mathrm{H}, \mathrm{CH}_{2}\right)\end{array}$ & $\begin{array}{l}2.15\left(\mathrm{~m}, 1 \mathrm{H}, \mathrm{CH}_{2}\right) \\
1.80\left(\mathrm{~m}, 1 \mathrm{H}, \mathrm{CH}_{2}\right)\end{array}$ & $\begin{array}{c}2.00^{\mathrm{c}} \\
1.70\left(\mathrm{~m}, 1 \mathrm{H}, \mathrm{CH}_{2}\right)\end{array}$ & $\begin{array}{c}2.50(\mathrm{dd}, 1 \mathrm{H}, \\
\left.J 14.5,6.7 \mathrm{~Hz}, \mathrm{CH}_{2}\right) \\
2.22\left(\mathrm{~m}, 1 \mathrm{H}, \mathrm{CH}_{2}\right)\end{array}$ & $2.40\left(\mathrm{~m}, 2 \mathrm{H}, \mathrm{CH}_{2}\right)$ \\
\hline 2 & $2.00\left(\mathrm{~m}, 2 \mathrm{H}, \mathrm{CH}_{2}\right)$ & $\begin{array}{c}2.95(\mathrm{dd}, 2 \mathrm{H}, J \text { 11.1 } \\
\left.\quad 3.5 \mathrm{~Hz}, \mathrm{CH}_{2}\right)\end{array}$ & $\begin{array}{c}2.04^{\mathrm{c}} \\
1.46(\mathrm{br} \mathrm{d}, 2 \mathrm{H}, \\
\left.J 11.2 \mathrm{~Hz}, \mathrm{CH}_{2}\right)\end{array}$ & - & $5.80\left(\mathrm{~m}, 1 \mathrm{H}, \mathrm{CH}_{2}\right)$ \\
\hline 3 & $5.19(\mathrm{~s}, 1 \mathrm{H}, \mathrm{CH})$ & - & $\begin{array}{l}3.50(\mathrm{brt}, 1 \mathrm{H} \\
J 2.3 \mathrm{~Hz}, \mathrm{CH})\end{array}$ & $9.93(\mathrm{~s}, 1 \mathrm{H}, \mathrm{CH})$ & $\begin{array}{c}6.05(\mathrm{~d}, 1 \mathrm{H}, \\
J 9.5 \mathrm{~Hz}, \mathrm{CH})\end{array}$ \\
\hline 4 & - & - & - & - & - \\
\hline 5 & - & & - & - & - \\
\hline 6 & $\begin{array}{c}1.71(\mathrm{~d}, 1 \mathrm{H}, \\
\left.J 12.3 \mathrm{~Hz}, \mathrm{CH}_{2}\right) \\
1.15\left(\mathrm{~m}, 1 \mathrm{H}, \mathrm{CH}_{2}\right)\end{array}$ & $\begin{array}{l}1.62\left(\mathrm{~m}, 1 \mathrm{H}, \mathrm{CH}_{2}\right) \\
1.25\left(\mathrm{~m}, 1 \mathrm{H}, \mathrm{CH}_{2}\right)\end{array}$ & $\begin{array}{c}1.64(\mathrm{~d}, 1 \mathrm{H}, \\
\left.J 13.2 \mathrm{~Hz}, \mathrm{CH}_{2}\right) \\
1.29(\mathrm{~d}, 1 \mathrm{H}, \\
\left.J 10.2 \mathrm{~Hz}, \mathrm{CH}_{2}\right)\end{array}$ & $\begin{array}{l}1.62\left(\mathrm{~m}, 1 \mathrm{H}, \mathrm{CH}_{2}\right) \\
1.31\left(\mathrm{~m}, 1 \mathrm{H}, \mathrm{CH}_{2}\right)\end{array}$ & $\begin{array}{l}1.88\left(\mathrm{~m}, 1 \mathrm{H}, \mathrm{CH}_{2}\right) \\
1.49\left(\mathrm{~m}, 1 \mathrm{H}, \mathrm{CH}_{2}\right)\end{array}$ \\
\hline 7 & $1.36\left(\mathrm{~m}, 2 \mathrm{H}, \mathrm{CH}_{2}\right)$ & $1.47\left(\mathrm{~m}, 2 \mathrm{H}, \mathrm{CH}_{2}\right)$ & $\begin{array}{l}1.49\left(\mathrm{~m}, 1 \mathrm{H}, \mathrm{CH}_{2}\right) \\
1.42\left(\mathrm{~m}, 1 \mathrm{H}, \mathrm{CH}_{2}\right)\end{array}$ & $1.52\left(\mathrm{~m}, 2 \mathrm{H}, \mathrm{CH}_{2}\right)$ & $1.43\left(\mathrm{~m}, 2 \mathrm{H}, \mathrm{CH}_{2}\right)$ \\
\hline 8 & $1.52(\mathrm{~m}, 1 \mathrm{H}, \mathrm{CH})$ & $1.47(\mathrm{~m}, 2 \mathrm{H}, \mathrm{CH})$ & $1.54(\mathrm{~m}, 1 \mathrm{H}, \mathrm{CH})$ & $1.39(\mathrm{~m}, 1 \mathrm{H}, \mathrm{CH})$ & $1.64(\mathrm{~m}, 1 \mathrm{H}, \mathrm{CH})$ \\
\hline 9 & - & - & - & - & - \\
\hline 10 & $1.39(\mathrm{~m}, 1 \mathrm{H}, \mathrm{CH})$ & $2.17^{\mathrm{c}}$ & $\begin{array}{c}1.92(\mathrm{~d}, 1 \mathrm{H}, \\
J 11.2 \mathrm{~Hz}, \mathrm{CH})\end{array}$ & $\begin{array}{c}1.76(\mathrm{dd}, 1 \mathrm{H}, \\
J 14.0,7.6 \mathrm{~Hz}, \mathrm{CH})\end{array}$ & $1.49(\mathrm{~m}, 1 \mathrm{H}, \mathrm{CH})$ \\
\hline 11 & $\begin{array}{c}5.44(\mathrm{~d}, 1 \mathrm{H}, \\
J 10.9 \mathrm{~Hz}, \mathrm{CH})\end{array}$ & $\begin{array}{c}5.10(\mathrm{~d}, 1 \mathrm{H}, \\
J 10.3 \mathrm{~Hz}, \mathrm{CH})\end{array}$ & $\begin{array}{c}5.40(\mathrm{~d}, 1 \mathrm{H}, \\
J 11.2 \mathrm{~Hz}, \mathrm{CH})\end{array}$ & $\begin{array}{c}5.12(\mathrm{dd}, 1 \mathrm{H}, \\
J 9.6,2,6 \mathrm{~Hz}, \mathrm{CH})\end{array}$ & $\begin{array}{c}5.33(\mathrm{~d}, 1 \mathrm{H}, \\
J 10.3 \mathrm{~Hz}, \mathrm{CH})\end{array}$ \\
\hline 12 & $\begin{array}{c}2.41(\mathrm{~d}, 1 \mathrm{H}, \\
\left.J 13.0 \mathrm{~Hz}, \mathrm{CH}_{2}\right) \\
2.24(\mathrm{t}, 1 \mathrm{H}, \\
\left.J 12.3 \mathrm{~Hz}, \mathrm{CH}_{2}\right)\end{array}$ & $\begin{array}{c}2.49(\mathrm{~d}, 1 \mathrm{H}, \\
\left.J 12.8 \mathrm{~Hz}, \mathrm{CH}_{2}\right) \\
2.32(\mathrm{~d}, 1 \mathrm{H}, \\
\left.J 12.9 \mathrm{~Hz}, \mathrm{CH}_{2}\right)\end{array}$ & $\begin{array}{c}2.63(\mathrm{~d}, 1 \mathrm{H}, \\
\left.J 14.3 \mathrm{~Hz}, \mathrm{CH}_{2}\right) \\
2.27(\mathrm{t}, 1 \mathrm{H}, \\
\left.J 10.2 \mathrm{~Hz}, \mathrm{CH}_{2}\right)\end{array}$ & $\begin{array}{l}2.33\left(\mathrm{~m}, 1 \mathrm{H}, \mathrm{CH}_{2}\right) \\
2.27\left(\mathrm{~m}, 1 \mathrm{H}, \mathrm{CH}_{2}\right)\end{array}$ & $\begin{array}{l}2.58\left(\mathrm{~m}, 1 \mathrm{H}, \mathrm{CH}_{2}\right) \\
2.18\left(\mathrm{~m}, 1 \mathrm{H}, \mathrm{CH}_{2}\right)\end{array}$ \\
\hline 13 & - & - & - & - & - \\
\hline 14 & $5.64(\mathrm{~s}, 1 \mathrm{H}, \mathrm{CH})$ & $5.66(\mathrm{~s}, 1 \mathrm{H}, \mathrm{CH})$ & $5.64(\mathrm{~s}, 1 \mathrm{H}, \mathrm{CH})$ & $5.69(\mathrm{~s}, 1 \mathrm{H}, \mathrm{CH})$ & $5.66(\mathrm{~s}, 1 \mathrm{H}, \mathrm{CH})$ \\
\hline 15 & - & - & - & - & - \\
\hline 16 & $2.14,\left(\mathrm{~s}, 3 \mathrm{H}, \mathrm{CH}_{3}\right)$ & $2.20\left(\mathrm{~s}, 3 \mathrm{H}, \mathrm{CH}_{3}\right)$ & $2.20\left(\mathrm{~s}, 3 \mathrm{H}, \mathrm{CH}_{3}\right)$ & $2.12\left(\mathrm{~s}, 3 \mathrm{H}, \mathrm{CH}_{3}\right)$ & $2.11\left(\mathrm{~s}, 3 \mathrm{H}, \mathrm{CH}_{3}\right)$ \\
\hline 17 & $\begin{array}{c}0.97(\mathrm{~d}, 3 \mathrm{H} \\
\left.J 6.1 \mathrm{~Hz}, \mathrm{CH}_{3}\right)\end{array}$ & $\begin{array}{c}0.98(\mathrm{~d}, 3 \mathrm{H} \\
\left.J 5.3 \mathrm{~Hz}, \mathrm{CH}_{3}\right)\end{array}$ & $\begin{array}{c}0.98(\mathrm{~d}, 3 \mathrm{H} \\
\left.J 6.2 \mathrm{~Hz}, \mathrm{CH}_{3}\right)\end{array}$ & $\begin{array}{c}0.87(\mathrm{~d}, 3 \mathrm{H} \\
\left.J 6.6 \mathrm{~Hz}, \mathrm{CH}_{3}\right)\end{array}$ & $\begin{array}{c}1.01(\mathrm{~d}, 3 \mathrm{H} \\
\left.J 5.6 \mathrm{~Hz}, \mathrm{CH}_{3}\right)\end{array}$ \\
\hline 18 & $1.57\left(\mathrm{~s}, 3 \mathrm{H}, \mathrm{CH}_{3}\right)$ & $1.35\left(\mathrm{~s}, 3 \mathrm{H}, \mathrm{CH}_{3}\right)$ & $1.20\left(\mathrm{~s}, 3 \mathrm{H}, \mathrm{CH}_{3}\right)$ & $1.99\left(\mathrm{~s}, 3 \mathrm{H}, \mathrm{CH}_{3}\right)$ & $\begin{array}{l}4.80\left(\mathrm{~s}, 1 \mathrm{H}, \mathrm{CH}_{2}\right) \\
4.66\left(\mathrm{~s}, 1 \mathrm{H}, \mathrm{CH}_{2}\right)\end{array}$ \\
\hline 19 & $1.04\left(\mathrm{~s}, 3 \mathrm{H}, \mathrm{CH}_{3}\right)$ & $0.87\left(\mathrm{~s}, 3 \mathrm{H}, \mathrm{CH}_{3}\right)$ & $1.18\left(\mathrm{~s}, 3 \mathrm{H}, \mathrm{CH}_{3}\right)$ & $0.89\left(\mathrm{~s}, 3 \mathrm{H}, \mathrm{CH}_{3}\right)$ & $1.05\left(\mathrm{~s}, 3 \mathrm{H}, \mathrm{CH}_{3}\right)$ \\
\hline 20 & $0.76\left(\mathrm{~s}, 3 \mathrm{H}, \mathrm{CH}_{3}\right)$ & $0.78\left(\mathrm{~s}, 3 \mathrm{H}, \mathrm{CH}_{3}\right)$ & $0.79\left(\mathrm{~s}, 3 \mathrm{H}, \mathrm{CH}_{3}\right)$ & $0.84\left(\mathrm{~s}, 3 \mathrm{H}, \mathrm{CH}_{3}\right)$ & $0.85\left(\mathrm{~s}, 3 \mathrm{H}, \mathrm{CH}_{3}\right)$ \\
\hline $11^{\prime}$ & $1.99\left(\mathrm{~s}, 3 \mathrm{H}, \mathrm{CH}_{3}\right)$ & $2.02\left(\mathrm{~s}, 3 \mathrm{H}, \mathrm{CH}_{3}\right)$ & $1.99\left(\mathrm{~s}, 3 \mathrm{H}, \mathrm{CH}_{3}\right)$ & $1.96\left(\mathrm{~s}, 3 \mathrm{H}, \mathrm{CH}_{3}\right)$ & $2.01\left(\mathrm{~s}, 3 \mathrm{H}, \mathrm{CH}_{3}\right)$ \\
\hline $15^{\prime}$ & $3.66\left(\mathrm{~s}, 3 \mathrm{H}, \mathrm{CH}_{3}\right)$ & - & - & - & - \\
\hline
\end{tabular}

${ }^{\text {a }}$ Spectra taken at $300 \mathrm{MHz}$; ${ }^{\text {b}} 500 \mathrm{MHz}$; ${ }^{\text {'overlapped. }}$ 
Table 2. ${ }^{13} \mathrm{C}$ NMR chemical shift $(\delta)$ of compounds $\mathbf{1}, \mathbf{2}, \mathbf{4}$ and $\mathbf{5}\left(\mathrm{CDCl}_{3}\right)$, and 3 (MeOD)

\begin{tabular}{|c|c|c|c|c|c|}
\hline Position & $\mathbf{1}^{\mathrm{a}}$ & $2^{\mathrm{a}}$ & $3^{b}$ & $4^{a}$ & $5^{b}$ \\
\hline 1 & 19.5 & 25.3 & 31.6 & 28.2 & 24.8 \\
\hline 2 & 27.3 & 51.4 & 19.0 & 137.9 & 128.1 \\
\hline 3 & 120.6 & 180.3 & 77.6 & 188.9 & 129.1 \\
\hline 4 & 144.5 & 82.7 & 76.9 & 159.6 & 156.8 \\
\hline 5 & 38.7 & 49.5 & 43.3 & 51.7 & 38.1 \\
\hline 6 & 36.9 & 29.9 & 33.8 & 33.9 & 37.1 \\
\hline 7 & 28.3 & 28.9 & 28.5 & 28.7 & 27.9 \\
\hline 8 & 36.2 & 36.7 & 37.2 & 37.2 & 36.9 \\
\hline 9 & 43.4 & 43.2 & 44.6 & 42.8 & 43.7 \\
\hline 10 & 47.5 & 45.7 & 42.5 & 51.5 & 44.5 \\
\hline 11 & 76.1 & 76.0 & 78.0 & 75.1 & 75.4 \\
\hline 12 & 41.8 & 42.6 & 42.9 & 42.6 & 41.9 \\
\hline 13 & 157.1 & 160.6 & 158.6 & 170.7 & 159.6 \\
\hline 14 & 118.1 & 118.1 & 119.6 & 118.1 & 117.9 \\
\hline 15 & 166.7 & 171.6 & 169.7 & 171.4 & 171.0 \\
\hline 16 & 18.9 & 19.1 & 19.0 & 19.2 & 19.2 \\
\hline 17 & 17.9 & 16.8 & 18.5 & 14.5 & 18.1 \\
\hline 18 & 18.2 & 22.3 & 21.3 & 9.8 & 107.5 \\
\hline 19 & 20.5 & 17.6 & 18.2 & 17.4 & 22.2 \\
\hline 20 & 12.1 & 12.8 & 12.5 & 16.4 & 12.4 \\
\hline $11-\mathrm{OAc}$ & $170.8 / 21.0$ & $170.9 / 21.0$ & $172.8 / 20.9$ & $170.8 / 21.0$ & $170.8 / 21.0$ \\
\hline $15-\mathrm{OMe}$ & 51.0 & - & - & - & - \\
\hline
\end{tabular}

${ }^{\mathrm{a}}$ Spectra taken at $300 \mathrm{MHz}$; ${ }^{\mathrm{b}} 500 \mathrm{MHz}$.

and halimane diterpenes which are not well common to the genus. The results reported in the present work indeed corroborate the tendency of $P$. ornatus to behave differently of the other species belonging to Plecthranthus. Nine (1-5, $\mathbf{7 , 8}, \mathbf{1 0}, 11$ ), out of eleven diterpenes reported here belong to the clerodane class, while the two others belong to the labdane (9) and abietane (6) classes, respectively. Two of the isolated ent-clerodanes $(\mathbf{2}, \mathbf{4})$ present an unusual $(4 \rightarrow 2)$-abeo-clerodane rearranged, while no halimane has been isolated in the present work. Unfortunately, none of the eleven isolated compounds showed any cytotoxic action, and the antimicrobial activity was too weak in order to be considered effective.

\section{Supplementary Information}

Supplementary information (Figures S1-S42) is available free of charge at http://jbcs.sbq.org.br as a PDF file.

\section{Acknowledgments}

This work was supported by grants from Conselho Nacional de Desenvolvimento Científico e Tecnológico (CNPq), Coordenação de Pessoal e Nível Superior (CAPES) and Programa de Núcleo de Excelência (PRONEX).

\section{References}

1. Alasbahi, R. H.; Melzig, M. F.; Planta Med. 2010, 76, 653; Rice, L. J.; Brits, G. J.; Potgieter, C. J.; Van Staden, J.; S. Afr. J. Bot. 2011, 77, 947.

2. Lukhoba, C. W.; Simmonds, M. S. J.; Paton, A. J.; J. Ethnopharmacol. 2006, 103, 1.

3. Waldia, S.; Joshi, B. C.; Pathak, U.; Joshi, M. C.; Chem. Biodiversity 2011, 8, 244.

4. Chen, Y. S.; Yu, H. M.; Shie, J. J.; Cheng, T. J. R.; Wu, C. Y.; Fang, J. M.; Wong, C. H.; Bioorg. Med. Chem. 2014, 22, 1766; Napagoda, M.; Gerstmeier, J.; Wesely, S.; Popella, S.; Lorenz, S.; Scheubert, K.; Svatos, S.; Werz, O.; J. Ethnopharmacol. 2014, 151, 800.

5. Albuquerque, R. L.; Kentopff, M. R.; Machado, M. I. L.; Silva, M. G. V.; Matos, F. J. A.; Quim. Nova 2007, 30, 1882.

6. Khare, R. S.; Banerjee, S.; Kundu, K.; Int. J. Pharma Bio Sci. 2011, 2, 488.

7. Xing, X.; Wu, H.; Wang, X.; Huang, Y.; Li, Q.; Li, C.; Yang, Y.; Liu, J.; J. Chemother. 2008, 20, 238.

8. Patel, R.; Mahobia, N. K.; Gendle, R.; Kaushik, B.; Singh, S.; Pharmacogn. Res. 2010, 2, 86.

9. Ascensão, L.; Mota, L.; Castro, M. M.; Ann. Bot. (Oxford, U. K.) 1999, 84, 437.

10. Dellar, J. E.; Cole, M. D.; Waterman, P. G.; Phytochemistry 1996, 41, 735; Passinho-Soares, H.; Felix, D.; Kaplan, M. A.; Margis-Pinheiro, M.; Margis, R.; Planta Med. 2006, 72, 929.

11. Abdel-Mogib, M.; Albar, H. A.; Batterjee, S. M.; Molecules 2002, 7, 271.

12. Mosmann, T.; J. Immunol. Methods 1983, 65, 55.

13. National Committee for Clinical Laboratory Standards; Document M7-A6; Methods for Dilution Antimicrobial Susceptibility Tests for Bacteria that Grow Aerobically; NCCLS: Wayne, PA, USA, 2003.

14. Arihara, S.; Ruedi, P.; Eugster, C. H.; Helv. Chim. Acta 1975, 58,343

15. Wijethne, E. M. K.; Silva, L. B.; Tezuka, Y.; Kikuchi, T.; Phytochemistry 1995, 39, 443.

16. Oliveira, P. M.; Ferreira, A. A.; Silveira, D.; Alves, R. B.; Rodrigues, G. V.; Emerenciano, V. P.; Raslan, D. R.; J. Nat. Prod. 2005, 68, 588.

17. Pacheco, A. G.; Oliveira, P. M.; Piló-Veloso, D.; Alcantara, A. F. C.; Molecules 2009, 14, 1245. 
18. Rijo, P.; Rodriguez, B.; Duarte, A.; Simões, M. F.; Nat. Prod. J. 2011, $1,57$.

19. Rijo, P.; Gaspar-Marques, C.; Simões, M. F.; Jimeno, M. L.; Rodriguez, B.; Biochem. Syst. Ecol. 2007, 35, 215.

20. Tsichritzis, F.; Jakupovic, J.; Phytochemistry 1990, 29, 3173.

21. Yang, S.-M.; Wu, S.-H.; Qin, X.-D.; Luo, X.-D.; Wu, D.-G.; Helv. Chim. Acta 2004, 87, 1279.

22. Tung-Ho, W.; Yung-Yi, C.; Chao-Jung, C.; Lean-Teik, N.; Li-Chen, C.; Li-Jiau, H.; Yung-Husan, C.; Sheng-Chu, K.; Mohamed, E.; Yang-Chang, W.; Fang-Rong, C.; Chih-Chuang, L.; Molecules 2014, 19, 2049.

23. Carneiro, V. A.; Santos, H. S.; Arruda, F. V. S.; Bandeira, P. N.; Albuquerque, M. R. J. R.; Pereira, M. O.; Henriques, M.; Cavada, B. S.; Teixeira, E. H.; Molecules 2011, 16, 190; Cardoso Sá, N.; Cavalcante, T. T.; Araújo, A. X.; dos Santos, H. S.;
Albuquerque, M. R.; Bandeira, P. N.; da Cunha, R. M.; Cavada, B. S.; Teixeira, E. H.; Arch. Oral Biol. 2012, 57, 550; Urzúa, A.; Jara, F.; Tojo, E.; Wilkens, M.; Mendoza, L.; Rezende, M. C.; J. Ethnopharmacol. 2006, 103, 297.

24. Vasconcelos, M. A.; Arruda, F. V. S.; Santos, H. S.; Rodrigues, A. S.; Bandeira, P. N.; Albuquerque, M. R. J. R.; Cavada, B. S.; Teixeira, E. H.; Henriques, M.; Pereira, M. O.; Ind. Crops Prod. 2014, 61, 509.

25. Urzúa, A.; Rezende, M. C.; Mascayano, C.; Vásquez, L.; Molecules 2008, 13, 882 .

Submitted: June 30, 2016

Published online: September 14, 2016

FAPESP has sponsored the publication of this article. 